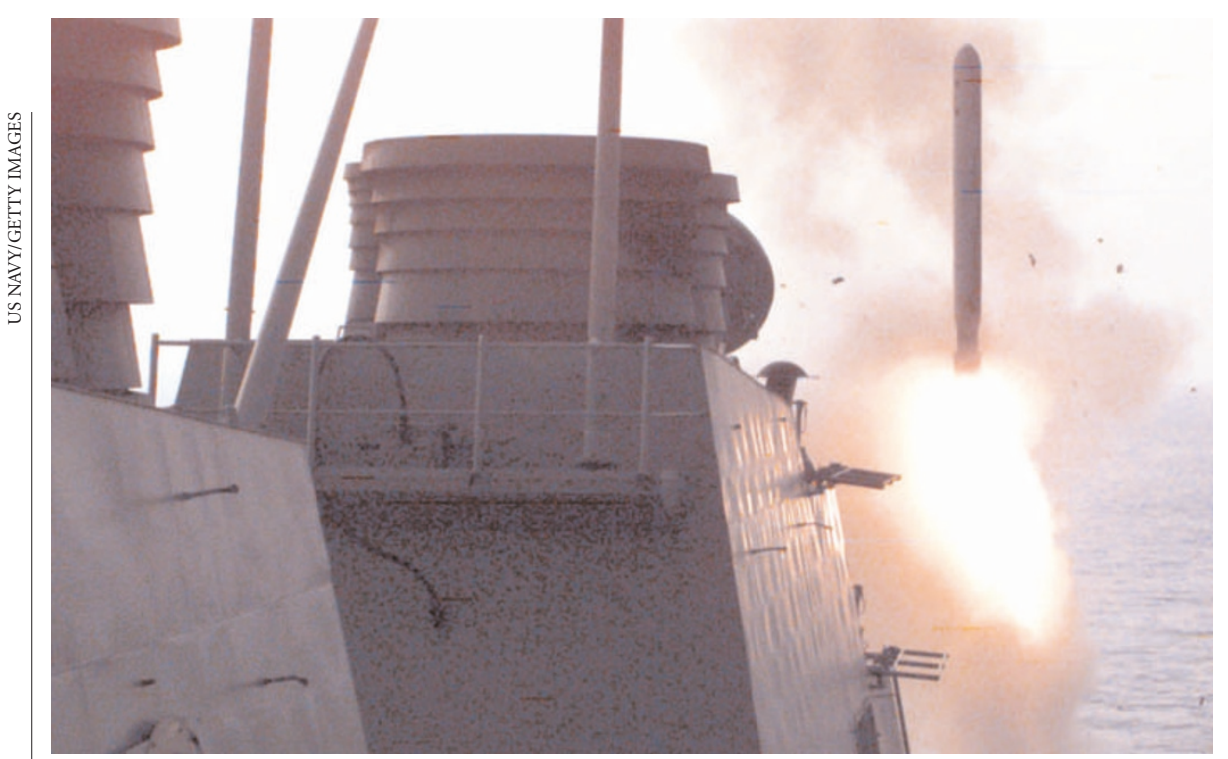

Defensive move: the US administration wants to enhance the capabilities of cruise missiles.

\title{
Democrats slam Bush plan for fresh nuclear weapons
}

\section{Geoff Brumfiel, Washington}

The Bush administration is pushing ahead with plans to research, and perhaps build, new kinds of nuclear weapons, angering critics who say that this will encourage global proliferation.

The programme was outlined by energy secretary Spencer Abraham and Linton Brooks, head of the National Nuclear Security Administration, at congressional hearings over the past two weeks. It would see some $\$ 500$ million spent on advanced concepts for nuclear weapons over the next five years. This would pay for research and development of a nuclear-tipped cruise missile with advanced navigation capabilities and a weapon known as a bunker buster, which could strike targets buried deep underground.

Leading Democrats lined up to denounce the plan, saying that the energy department has other nuclear-weapons priorities that seem to be suffering at the expense of the new programme. "You're rushing ahead with new nuclear weapons including mini-nukes and nuclear bunker busters," said Senator Edward Kennedy (Democrat, Massachusetts). "But you're cutting funds for nuclear security."

Since the Bush administration unveiled its nuclear doctrine in 2001, officials have advocated the development of low-yield nuclear weapons that might be used against hardened or deeply buried targets without causing massive civilian casualties. They have also argued that working on such weapons will strengthen the skills at the nuclearweapons labs - Lawrence Livermore in California, and Los Alamos and Sandia in New Mexico (see Nature 415, 945-946; 2002). But critics counter that the availability of the weapons will increase the possibility that they will be used, by the United States or by others.
The president's budget for 2005 proposes that funding for research on "advanced concepts" should increase by $50 \%$ to $\$ 9$ million. According to Abraham, much of that would go towards developing a cruise missile that could be retargeted after launch and would incorporate new safeguards against accidental detonation. Funding for research into a hardened warhead designed to destroy deeply buried targets would also increase from $\$ 7$ million to $\$ 27$ million.

But Democrats are angry at a five-year plan for these projects, contained in a fiveyear forecast of the budget, which suggests spending roughly $\$ 450$ million for the development of the bunker-busting weapon between 2006 and 2009.

Abraham told the hearings that, for the moment, the weapons labs are carrying out only paper studies and have no plans to build or test new weapons. "All we are offering Congress is a cost assessment of what the programmes might be," he said.

But some observers say that the five-year plan exposes the administration's real intentions. "Having budget numbers that extend through the development phase makes it harder for the administration to convince senators that this is just a research project," says Michael Levi, a physicist at the Brookings Institution, a think-tank in Washington DC. "This indicates to me that the administration clearly intends to move forward," adds Daryl Kimball, executive director of the Washington-based Arms Control Association, which advocates non-proliferation.

Last year, congressional opposition halved the administration's funding proposal for research into the bunker buster. This year, with an election at stake, it can expect an even tougher fight.

\section{Australia considers revised scheme for young researchers}

Carina Dennis, Sydney

Australia is seeking to revamp a training scheme for young scientists that has been irking the nation's universities.

The change is proposed in reviews of Australian research, released on 24 March, which also called for $\mathbf{A} \$ 500$ million (US\$375 million) to be spent on boosting collaboration between institutions, and for a top-level advisory council to be set up to guide national science policy.

The three reviews looked at university research funding, research infrastructure and collaborations between universities and public research agencies. The government is expected to take them into account in a long-term budget plan to be released next month.

The recommendations include an overhaul of the nation's $\mathbf{A} \$ 540$ million per year research training scheme (RTS), which funds postgraduate students. Universities have complained that the complex formula it uses to allocate funding penalizes universities whose students complete their courses early.

Last year, for example, the University of Melbourne began legal action against the federal government for revenue it claims it lost because of the scheme. "The university estimates it has lost more than A \$10 million over the past three years," says Kwong Lee Dow, its vice-chancellor.

Federal science minister Brendan Nelson said after the reviews were released that the government would be making some changes to the RTS.

The reviews, conducted by scientists and government officials, also called for A \$500 million to be spent over ten years to drive collaborations among universities, research agencies and industry.

"I am fairly optimistic that there will be funding for this, and I'm hopeful it will be on top of existing budgets," says Kurt Lambeck, a geophysicist at the Australian National University in Canberra.

The reviews further suggest creating a strategic research council to make decisions about national research policy. This is seen as a mechanism for getting the main research agencies to work more closely together. But some people worry that it could just create more bureaucracy.

"There is no real indication of what the structure or function of the council would be," says Snow Barlow, an environmental physiologist at the University of Melbourne and president of the Federation of Australian Scientific and Technological Societies. 